\title{
BRIEF ANALYSIS OF COMPETITION DEFENSE IN BRAZIL
}

Augusto Jaeger Junior

Master of Law/UFSC and PhD/UFRGS. Professor of Law School at UFRGS, Porto Alegre, Brazil.

Daniela Copetti Cravo

Social Policy Analyst, Federal Govenment, Brazil. Master of Law /UFRGS.

Abstract: The primary aim of this arcticle is to analyse the Brazilian Competition Policy System (BCPS) in terms of its design, its challenges and its evolution. Furthermore, it seeks to give an overview of the large and recent modifications experienced by the antitrust institutional and normative drawing in Brazil, which will greatly contribute to the freedom of the market and the welfare of the consumers.

Keywords: Antitrust - Brazilian Competition Policy System - Freedom of the market - Welfare of the consumers.

\section{INTRODUCTION}

The defense of free competition aims to ensure an efficient allocation of resources in the economy, in order to promote the increase of the overall levels of employment fee and population income, as well as economic growth, and prevent undue shift income between supplier and consumer, and even the exclusion of a portion of the population from the consumer markets. Antitrust, therefore, transcend the interest of the parties directly involved, being the society the owner of the legal interests protected by that.

In Brazil, the protection of competition begins to take on a greater role from the Federal Constitution of 1988, that listed free competition as a principle of economic order, and, aditionally, from the edition of the Law 8.884/94. This Federal legislation sketched the aintitrust system, inaugurating the Brazilian Competition Policy System (BCPS).

The primary objective of this article is to analyze this system, with regard to its design, its challenges and its evolution. Furthermore, it seeks to give an overview of the large and recent modifications 
experienced by the antitrust institutional and normative drawing in Brazil, which will greatly contribute to the freedom of the market and to the welfare of the consumers.

\section{ANTITRUST IN BRAZIL}

Brazilian State assumes, with the guidance given by The Constitution of 1988, a new phase, as a normative and regulating agent. Therefore, it gradually ceases to be an economic agent and starts to ensure the access, to private enterprise, of sectors so far reserved to itself.

The praise of free enterprise and, consequently, the capitalist system, however, is not absolute, being limited by the precepts and principles established in the Constitution, that besides restricting the exercise of economic activity, also impose on the State a normative and regulatory role, constituting, according to Claudia Lima Marques ${ }^{1}$, the "public economic order" 2 . In this catalog, likewise, lie the free competition $^{3}$ and the consumer protection, which were raised for the first time in 1988, to principles of Economic Order ${ }^{4}$.

The protection of free competition intends to ensure the efficient allocation of resources in the economy, in order to encourage an increase in overall employment levels, population income levels and economic growth, and prevent undue shift income between supplier and the exclusion of a portion of the population from the consumer markets. Antitrust, therefore, transcend the interest of the parties directly involved, being the society the owner of the legal interests protected by that, as already seen.

In order to improve and systematize the matter relating to the

1 MARQUES, Cláudia Lima. Contratos no Código de Defesa do Consumidor: O Novo Regime das Relações Contratuais. 5. Ed. São Paulo: Revista dos Tribunais, 2005, p. 597.

2 Bruno Miragem complements the information, stating that as part of the positive constitucional order, the Consumer Protection, by express determination of the Federal Constitution of 1988, can not be dismissed or overlooked in the activity of economic regulation. MARQUES, Claudia Lima; BENJAMIN, Antonio Herman; MIRAGEM, Bruno. Comentários ao código de defesa do consumidor. São Paulo, Revista dos Tribunais, 2006, p. 1149.

3 To Isabel Vaz, free competition is "the action developed by a large number of competitors, acting freely on the market of a given product, so that supply and demand come from buyers or sellers whose equal conditions prevent them from influencing, in a permanent and lasting way, at the the prices of goods or services". VAZ, Isabel. Direito Econômico da Concorrência. Rio de Janeiro, Forense, 1993, p. 27.

4 In that sense, Marques exposes: "The Constitution of 1988, for the first time in the history of Brazilian constitutional texts, expressly provides for the protection of consumers, identifying them as a group to be especially protected by State action”. MARQUES, Cláudia Lima. Contratos no Código de Defesa do Consumidor: O Novo Regime das Relações Contratuais. 5. Ed. São Paulo, Revista dos Tribunais, 2005, p. 595. 
constitutional principle of free competition, the Law $\mathrm{n}^{\circ}$. 8.884/94 was issued. The enactment of this legislation, in the words of Paula Forgioni $i^{5}$, "systematizes antitrust matters, in order to improve its legislative treatment", with the implementation of the BCPS, which is the main responsible, in Brazil, for the protection of competition. This system, under the aegis of the Law $n^{\circ} 8.884 / 94$, was mainly composed by CADE (Administrative Council of Competitive Defense) and two more bodies attached to different ministries: the Secretariat of Economic Law (SDE), of the Ministry of Justice, and the Secretariat for Economic Monitoring (SEAE), of the Ministry of Finance.

The BCPS works with a view to two different approaches. The first refers to the repressive role, also known as behaviors control, which seeks to investigate and prosecute possible violations of the economic order comitted by economic agents. The second, is the preventive or stuctures control role, where the concentration acts, regardless of its manifestation, which may limit or otherwise restrain open competition, or result in the domination of relevant goods or services, shall be submitted for examination to the SBDC.

Although the defense of competition is held in essence by the BCPS agencies, it is no less true that the Regulatory Agencies also exercise powers regarding to the competition matters, within their respective sectors. Clear that such assignment, with some exception, is generic, but not nonexistent.

\section{PARADIGMATIC CASES OF BCPS}

During the term of the Law $n^{\circ} 8.884 / 94$, the BCPS has acted in a fairly intense manner - and with great visibility - in defense and dissemination of competitive environment. To well illustrate this governance of the institutions involved, we collate some paradigmatic cases.

In the framework of preventive control, we cite the case AMBEV. The firms 'Companhia Antarctica Paulista' and 'Companhia Cervejaria Brahma' celebrated corporate acts in order to bring together under common control their respective subsidiaries, through the establishment of a new corporation, called 'Companhia de Bebidas das Americas $\mathrm{AmBev}^{6}$. In the Concentration Act N $.08012 .005846 / 1999-12^{7}$, CADE

5 FORGIONI, Paula Andréa. Os Fundamentos do Antitruste. 3. ed. São Paulo, Editora Revista dos Tribunais, 2008, p. 143.

6 CONSELHO ADMINISTRATIVO DE DEFESA ECONÔMICA - CADE. Guia Prático do CADE: A Defesa da Concorrência no Brasil. São Paulo, CIEE, 2007.

7 BRASIL. CONSELHO ADMINISTRATIVO DE DEFESA ECONÔMICA. Concentration Act $n^{\circ}$ 08012.005846/1999-12. Parts: Cervejarias Kaiser Brasil Ltda, Companhia Cervejaria Brahma and others. Reporter: Councillor Hebe Teixeira Romano Pereira da Silva. 
understood that the constitution of AMBEV "would result in increased productivity, improvement in the quality of goods offered and generate efficiencies and technological development to outweigh the potential harm to competition arising from the association". Nevertheless, CADE has not ignored the fact that the substantial elimination of the portion of the competition in the beer market, approving, thus, the operation with restrictions embodied in a Performance Term of Commitment (TCD), which stated:

The TCD determined the implementation of the so-called "integrated set of measures" (subclause 2.1), that comprised the selling of the trade mark 'Bavária', the sale of 5 (five) factories and the sharing of the distribution. Besides, AMBEV should share its distribution network in each of the five relevant markets defined (subclause 2.2), disable other factories only through public offering (subclause 2.3), maintain the level of employment, and any layoffs associated with the corporate restructuring should be accompanied by programs of retraining and relocation (subclause 2.4), not to impose exclusivity outlets (subsection 2.5) and adopt all measures to achieve the relevant efficiencies to fusion (subsection 2.6). ${ }^{8}$

Still in control of structures, it must be mentioned the case 'Sadia' and 'Perdigão' . The parties have signed, in 2009, an Association Agreement, unifying its operations, to the extent that 'Sadia' became a wholly owned subsidiary of 'BRF - Brazil Foods'.

When the act was submitted to the assessment of BCPS, thus stood Councillor Emmanuel Joppert Carlos Ragazzo:

In reality, the fact is that even if, ad argumentandum, were all considered synergy gains claimed by the parties, the magnitude of such efficiencies, still proves insignificant in the light of the serious harm to the community that this merger will generate. The potential harm to consumers arising from this operation, as was demonstrated to exhaustion, is

8 CONSELHO ADMINISTRATIVO DE DEFESA ECONÔMICA - CADE. Guia Prático do CADE: A Defesa da Concorrência no Brasil. São Paulo: CIEE, 2007.

9 BRASIL. CONSELHO ADMINISTRATIVO DE DEFESA ECONÔMICA. Concentration Act n. ${ }^{\circ}$ 08012.004423/2009-18. Parts: Perdigão S. A. e Sadia S. A. Reporter: Councillor Carlos Emmanuel Joppert Ragazzo. 
substantial to a degree rarely seen (...).Certainly, the mere comparison of alleged synergy gains with the results of price increases arising from simulation tests and UPPs not serve by itself, to attest that there was a transfer of efficiencies to consumers (...).This probably occur because, still, the transfer of the efficiencies to consumers would be too uncertain (...). That said, it is concluded, quite clearly, that the potential efficiencies resulting from the operation are not even remotely sufficient to compensate for the extreme damage to consumers and the community generated by this merger ${ }^{10}$.

Although the Reporting Commissioner Emmanuel Joppert Ragazzo have understood by non-approval of the act, the operation remains endorsed, with restrictions, through the assignment of the Term of Commitment to Performance on July 13, 2011. This term has established a number of requirements for the approval of the transaction, such as selling assets and brands.

In relation to repressive control, the BCPS, in recent years, has been spending much of its energy to combat cartels. Proof of this is the formulation and implementation of the Brazilian Program on Fighting Cartels, recognized, by the way, even internationally.

One of the most visible cases was, undoubtedly, the Administrative Proceeding $\mathrm{N}^{\mathrm{o}}$ 08012009888/2003-70, which had as rapporteur the Councillor Fernando Magalhães Furlan ${ }^{11}$. In this case, CADE understood that there was a cartel formation in the gas sector, whether industrial or healthcare related.

As a result of such conviction, there was a fine totaling $\mathrm{R} \$ 2.3$ billion, to companies 'White Martins Gases Industriais Ltda.', 'Air Liquide Brazil Ltda.', 'Air Products Brazil Ltda.', 'Linde Gases Ltda.', successor of 'AGA S.A.', and 'Industria Brasileira de Gases' and its officers and employees. This fine was regarded as the highest fine in the history of CADE, confirmed in 2012 by the Brazilian Federal Court of the 1st Region (TRF $1^{\mathrm{a}}$ Região).

Nevertheless, CADE has also been making effort in order to repress unilateral conduct of abuse of dominant position. This is the case of the administrative process n. $^{\circ} 08700.003070 / 2010-14$, which

10 BRASIL. CONSELHO ADMINISTRATIVO DE DEFESA ECONÔMICA. Concentration Act n. ${ }^{\circ}$ 08012.004423/2009-18. Parts: Perdigão S. A. e Sadia S. A. Reporter: Councillor Carlos Emmanuel Joppert Ragazzo.

11 BRASIL. CONSELHO ADMINISTRATIVO DE DEFESA ECONÔMICA. Administrative Process n ${ }^{\circ}$ 08012009888/2003-70. Reporter: Coucillor Fernando Magalhães Furlan. Judged on September 1st, 2010. 
aims to establish violations of the Law $n^{0} 8.884 / 94$, practiced by the Bank of Brazil, through the celebration of contracts with public entities with exclusivity clause for the assignment on the payroll.

The case was resolved through the celebration of a Term Commitment of Cessation of Practice between Bank of Brazil and CADE, pledging the Bank of Brazil to end the requirement of exclusivity in credit factored in all contracts with public agencies. The Term also established the payment by the Bank of Brazil, of a contribution to the Fund for the Defence of Diffused Rights of $\mathrm{R} \$ 99,476,840.00$.

It is clear, therefore, that the performance of Brazilian antitrust authorities was very relevant during the term of Law $\mathrm{n}^{\circ} 8.884 / 94$. Despite international recognition and consolidation of CADE as an institution, reforms to the system were needed, for at least a decade, both for new challenges, or to preserve gains already achieved.

\section{REFORMS IN THE SYSTEM}

The triggering event to the reform of the rules in antitrust in Brazil lies in the design of the BCPS, which was considered by many as inefficient. In view of the inability to optimize the system by infralegal means, arises the proposal for a legislative amendment.

The proposal began in the House of Representatives with the Bill $\mathrm{n}^{\mathrm{o}} 3.937 / 2004$, which considered specific and punctual changes on the Competition Law. The legislative process was complemented with another Bill, $\mathrm{n}^{\mathrm{o}} 5.877 / 2005$, which was appended to the Bill $\mathrm{n}^{\circ}$ 3.937/2004 and a substitute, which aimed to repeal the Law ${ }^{\circ} 8.884 / 94$.

Being the restructuring of the BCPS included in the Growth Acceleration Program (PAC), the bill was approved in plenary by the House of Representatives and transformed into a legal norm, subject to presidential approval. On December 1st, 2011, was then enacted the Law $n^{0} 12.529 / 11$, which had a vacatio legis period of 180 days from the date of its publication. This, finally, came into being on May 29th, 2012.

The change stamped on this Act, as noted by César Costa Alves Mattos $^{12}$, embeds deep institutional change, which seeks, by decreasing the relationship of economic agents with three branches, namely, SDE, SEAE and CADE, to rationalize the Brazilian System of Competition Defense. Within the proposed format, the new structure of CADE includes a General-Superintendence with an Attorney General, a Department of Economic Studies and an Administrative Tribunal.

Thus, in order to eliminate the Via Crucis of three counters, the

12 MATTOS, César. Bill no 5877/2005 - Reestrutura o Sistema Brasileiro de Defesa da Concorrência (SBDC) <http://www.econ.puc-rio.br/pdf/seminario/2007/Resumo\%20 Projeto\%20de\% 20Lei\%205877.pdf $>$. Accessed on February 11, 2012. 
SDE withdraws from BCPS: their competencies are now assigned to the General-Superintendence of CADE. Already SEAE becomes the true advocate of competition.

One of the major innovations brought with the edition of the new law refers to the notification of concentration acts, that ceases to be after the consummation of the act. The approval of CADE, therefore, will be a previous condition to the implementation of the operation.

The appraisal by CADE, as well, shall have a fixed term, which will be a maximum of 240 (two hundred and forty) days from the date of application protocol or its amendment. This period may be extended, if necessary, in only two hypothesis: (i) upon parties involved in the transaction request, for up to sixty (60) unextendable days; or (ii) by informed decision of the Court for up to ninety (90) unextendable days. Beyond this period, it was determined that, with the new law, the concentration acts will be given priority over processes tha investigate anticompetitive behaviours.

The criteria for notification of mergers have also changed. As the original wording, shall be subject to approval by CADE transactions in which (i) at least one of the economic groups involved in the operation have registered in the last balance sheet, annual gross sales in Brazil, in the year preceding the operation, equal or greater than $\mathrm{R} \$ 400,000,000.00$ (four hundred million reais), and (ii) at least one business group involved in the operation have been registered in the last balance sheet, annual gross sales in Brazil, greater than or equal to $\mathrm{R} \$ 30.000 .000,00$ (thirty million reais).

Worth mentioning that as soon as the legislation came into force the concentration acts have already started to observe new minimum, in view of the Interministerial Ordinance MJ / MF n. ${ }^{\circ} 994$ of May 30, $2012^{13}$. The billing of $\mathrm{R} \$ 400,000,000.00$ (four hundred million reais), initially required by Law, was replaced by $\mathrm{R} \$ 750,000,000.00$ (seven hundred and fifty million reais) and the billing of $\mathrm{R} \$ 30.000 .000,00$ (thirty million reais), by the $\mathrm{R} \$ 75.000 .000,00$ (seventy five million reais $)^{14}$.

13 BRASIL. Interministerial Ordinance MJ/MF n. ${ }^{\circ} 994$ de 30 de maio de 2012. Diário Oficial: May 30, 2012.

14 To Elizabete Farina and Fabiana Tito, "the effect of this change will be the reduction of the number of notified cases, releasing tangible and intangible resources for a more careful analysis of complex cases and also for investigation of anticompetitive, the heart of competition defense. Earns up process efficiency". FARINA, Elizabete; TITO, Fabiana. Nova Era de Defesa da Concorrência Brasileira. <http://www.ibrac.org.br/Noticias.aspx?id=1639>. Accessed on March 4, 2013. However, we must warn that this criterion very high, comparable to that criterion quite sophisticated economies, can be a setback to the achievements of Antitrust, allowing agents with significant market power, but far from reaching the new criteria billing exemptions from the antitrust prior control. 
In addition, the new Antitrust Act embraced new criteria for setting penalties for commission of offenses against the economic order. According to the letter of the law, the practice of violations of the economic order, in the case of a firm, will subject to a fine of $0.1 \%$ (one tenth percent) to 20\% (twenty percent) of the gross value obtained by the company, group or conglomerate, in the last year prior to the initiation of administrative proceedings, in the field of business activity in which the offense occurred, which will never be less than the benefit received, when it is possible its estimation ${ }^{15}$.

Another relevant change implemented by the new law refers to a fine for litigants in bad faith, foreseen in the trird paragraph of article 65 , in the Law $n^{0} 12.529 / 11$. Interestingly, there was no equivalent prediction in the Law $\mathrm{n}^{\circ} 8.884 / 94$.

On the cathalog of violations of the economic order, specific changes can be seen, particularly the removal of certain behaviors, such as exclusivity agreements. Nevertheless, it should be emphasized that even the conducts that were removed from the list may be configured as an infraction of economic order, as long as they have as object or may produce the effects enumerated in the article 36, of Law $\mathrm{N}^{\circ} .12 .529 / 11$ (items I to IV), even though not achieved, which supports the exemplary nature of the list.

These were, in general, the major changes brought to the BCPS, which came to be with the promulgation of Law $N^{\circ}$. 12.529/11. We conclude that the system and, in particular, the CADE has come to an apparatus legislative and institutional modern enough to face the new challenges that lie ahead.

15 Among the novelties introduced by the new law, no doubt, the issue of penalty will be one that will bring much discussion to CADE, academy, economic agents, consumers and even the judiciary. The first question would be to check if, indeed, the law was more beneficial or not to run, passive part of an administrative procedure within CADE. Second, and most beneficial, we must study the compulsory or not their feedback, extending and applying the rule contained in Article 5., Item XL 1988 Constitution. Finally, again considering that the standard would be more beneficial, is to be concluded by the setback of the new law, which will ultimately encouraging the practice of violations of the economic order, as well raised by Gabriel Pinto Moreira. MOREIRA, Gabriel Pinto. A infração Compensa na Nova Lei de Defesa da Concorrência? <http://www.valor.com.br/opiniao/3004748/infracao-compensa-nanova-lei-de-defesa-da-concorrencia\#ixzz2Mc1d7oN3 $>$. Accessed on March 4, 2013. We must have in mind, only complementing the negative aspect of the new law in order to decrease the sentencing criteria, that although it emphasizes that the penalty will never be less than the benefit, in practice this is very difficult to estimate. In that sense, we have the OECD study on the effectiveness of sanctions, and that highlights this problem: ORGANIZATION FOR ECONOMIC COOPERATION AND DEVELOPMENT. Fighting Hard Core Cartels: Harm, Effective Sanctions and Leniency programmes. Paris, 2002. <http://www.oecd.org/ dataoecd/41/44/1841891.pdf>. Accessed on April 20, 2012. 


\section{CONCLUSION}

As seen in this article, the Competition Defense in Brazil is getting closer to its maturity. Despite the wide spread of activities undertaken by the BCPS and the consolidation of the institutional authorities of the system during the term of the Law $n^{\circ} 8.884 / 94$, it is only with the enactment of the Law $\mathrm{n}^{\circ} 12.529 / 11$ that the BCPS, now with reduced number of members, starts to have a modern normative apparatus and fit for the performance of its institutional missions.

Facing difficult cases, which often stress the need to ensure political and economic independence of the antitrust authorities, the BCPS gained prominence in society and before the economic agents. So much is that, this year, through the work of the CADE, Brazil has reached record position among the world's antitrust authorities and obtained, for the first time, four in five possible stars, on the ranking in the "Global Competition Review", British magazine specialized in antitrust.

Evidently there is not only praise for the system. Many challenges are put to CADE and the BCPS with this new legislation. Among these are the need for a speedy trial by CADE of concentration acts, considering, mainly, that the analysis becomes prior to the implementation of the act. At the same time, BCPS must expend the same energy to the repression of anticompetitive behavior, which can not be neglected, lest there be a great loss to society as a whole.

\section{REFERENCES}

BRASIL. CONSELHO ADMINISTRATIVO DE DEFESA ECONÔMICA. Concentration Act no 08012.005846/1999-12. Parts: Cervejarias Kaiser Brasil Ltda, Companhia Cervejaria Brahma e outras. Reporter: Coucillor Hebe Teixeira Romano Pereira da Silva.

CONSELHO ADMINISTRATIVO DE DEFESA

ECONÔMICA. Administrative Process n ${ }^{\circ}$ 08012.009888/2003-70. Reporter: Coucillor Fernando Magalhães Furlan. Judged on September 1 st, 2010.

CONSELHO ADMINISTRATIVO DE DEFESA ECONÔMICA. Concentration Act no 08012.004423/2009-18. Parts: Perdigão S. A. e Sadia S. A. Reporter: Coucillor Carlos Emmanuel Joppert Ragazzo.

. Interministerial Ordinance MJ/MF n. ${ }^{\circ} 994$ de 30 de maio de 2012. Diário Oficial: May 30, 2012.

CONSELHO ADMINISTRATIVO DE DEFESA ECONÔMICA CADE. Guia Prático do CADE: A Defesa da Concorrência no Brasil. São Paulo, CIEE, 2007. 
FARINA, Elizabete; TITO, Fabiana. Nova Era de Defesa da Concorrência Brasileira. <http://www.ibrac.org.br/Noticias.aspx?id=1639>. Acessed on March 4, 2013.

FORGIONI, Paula Andréa. Os Fundamentos do Antitruste. 3. ed. São Paulo, Editora Revista dos Tribunais, 2008.

MARQUES, Cláudia Lima. Contratos no Código de Defesa do Consumidor: O Novo Regime das Relações Contratuais. 5. Ed. São Paulo, Revista dos Tribunais, 2005.

; BENJAMIN, Antonio Herman; MIRAGEM, Bruno. Comentários ao código de defesa do consumidor. São Paulo, Revista dos Tribunais, 2006.

MATTOS, César. Projeto de Lei 5877/2005 - Reestrutura o Sistema Brasileiro de Defesa da Concorrência (SBDC). <http://www.econ.pucrio.br/pdf/seminario/2007/Resumo\%20Projeto\%20de\%20Lei\%205877. pdf $>$. Acessed on February 11, 2012.

MOREIRA, Gabriel Pinto. A infração Compensa na Nova Lei de Defesa da Concorrência? <http://www.valor.com.br/opiniao/3004748/infracaocompensa-na-nova-lei-de-defesa-da-concorrencia\#ixzz2Mc1d7oN3>. Acessed on March 4, 2013.

ORGANIZATION FOR ECONOMIC COOPERATION AND DEVELOPMENT. Fighting Hard Core Cartels: Harm, Effective Sanctions and Leniency programmes. Paris, 2002. <http://www.oecd. org/dataoecd/41/44/1841891.pdf>. Acessed April 20, 2012.

VAZ, Isabel. Direito Econômico da Concorrência. Rio de Janeiro, Forense, 1993. 